\title{
Physical activity in university student athletes, prior and in confinement due to pandemic associated with COVID-19 \\ Actividad física en estudiantes deportistas universitarios, previo y en el confinamiento por pandemia asociada al COVID-19
}

Edgar Ismael Alarcón Meza, Javier Arturo Hall-López

Universidad Autónoma de Baja California (México)

\begin{abstract}
Objective: To compare the levels of physical activity in university athletes before and during the confinement due to pandemic associated with COVID-19. Method: thirty-two university student athletes enrolled in the Sports Faculty of the Autonomous University of Baja California. The average age of the participating subjects was $21.4 \pm 3.6$ years (17 men and 15 women). To assess the physical activity level, the international physical activity questionnaire (IPAQ) was used; measurements were carried out before and during confinement by COVID-19. Results: To determine equality of variance, the Student's t-test for independent samples was applied, with less physical activity (-33.6 Ä\%), MET-minutes/week during confinement by COVID-19 ( $\mathrm{p}=.005)$. Conclusions: Despite decreasing physical activity, the university athlete performed physical activity at home during confinement by COVID-19, harmonizing the time in the learning processes in their future profession.
\end{abstract}

Key words: Physical activity, COVID-19, University, Students.

Resumen. Objetivo: Comparar los niveles de actividad física en deportistas universitarios antes y durante del confinamiento por pandemia asociada al COVID-19. Método: treinta y dos estudiantes deportistas universitarios matriculados en la Facultad de Deportes de la Universidad Autónoma de Baja California. La edad promedio de los sujetos participantes fue 21.4 \pm 3.6 años (17 hombres y 15 mujeres). Para evaluar los niveles de actividad física, se utilizó el cuestionario internacional de actividad física (IPAQ), las mediciones se llevaron a cabo previo y en el confinamiento por pandemia asociada al COVID-19. Resultados: Para determinar la igualdad de varianza, la prueba t de Student para muestras independientes que resultó con menor actividad física (-33.6 ̈̈\%), MET-minutos/semana antes que durante el confinamiento por COVID-19 ( $\mathrm{p}=.005$ ). Conclusiones: A pesar de disminuir la actividad física, el deportista universitario realizó actividad física en su hogar durante el confinamiento por COVID-19, armonizando el tiempo en los procesos de aprendizaje en su futura profesión.

Palabras clave: Actividad física, COVID-19, Universidad, Estudiantes.

\section{Introduction}

The social confinement for the prevention of the transmission of COVID-19 has limited the practice of physical exercise in the population (Blocken, et al., 2020). Due to the etiological conditions of transmission of the disease, sports events have been canceled (Corsini, et al., 2020; Gallego, et al., 2020); and it has been recommended to exercise at home (Cortis, et al., 2020), such as aerobic exercise, resistance training with one's own weight, dancing, using ergometers and stationary bikes (Hammami, et al., 2020), physical activity with moderate to vigorous intensity being the most effective (Dixit, et al., 2020), which, despite the COVID-19 confinement, it is essential for highly competitive athletes to look for alternatives in order to maintain physical condition for when sports competitions are reactivated (Leng, \& Phua, 2020).

University athletes maintain a complex relationship between studies and sport, which involves effort and maintaining a special organization to meet academic and sports goals (Álvarez Pérez, et al., 2015; Blanco García, \& Burillo Naranjo, 2017). Universities approach sport as part of the comprehensive training of students (Corbí, et al., 2018; Rico-Díaz, et al., 2019), due to scientific evidence that indicates that university study time in young adults coincides with the onset of an increased sedentary lifestyle and body fat percentage (Sacheck, et al., 2010; Ochoa-Martinez, et al., 2017).

\footnotetext{
Fecha recepción: 10-02-20. Fecha de aceptación: 23-08-20

Javier Arturo Hall-López

javierhall@uabc.edu.mx
}

Currently, derived from the COVID-19 pandemic, universities have joined social confinement with action plans to prevent contagion, among which is to close sports facilities, and provide recommendations for sports practice (Wang, et al., 2020; Toresdahl, \& Asif, 2020). Therefore, in order to harmonize the process of learning and sports practice, tutoring and monitoring become a key factor (Álvarez Pérez, \& López Aguilar, 2012; Álvarez Pérez, \& López Aguilar, 2013). Regarding sports practice, instruments have been designed to identify the most suitable places for physical activity in the population during this COVID-19 health crisis (de Oliveira Neto, et al., 2020). Systematic reviews have identified the International Physical Activity Questionnaire (IPAQ) (Craig, et al. 2003), as the most utilized instrument to assess the level of physical activity in university students (Moreno-Arrebola, et al., 2018; Mella-Norambuena, et al., 2019). In this research, the Google Drive tool was utilized to virtually asses physical activity (Álvarez Ferrón, \& Sánchez Cañizares, 2014), using the IPAQ (Craig, et al. 2003), determined the level of physical activity in university athletes before and during confinement due to the COVID-19 pandemic.

\section{Methodology}

\section{Participants}

The research was performed utilizing a cross-sectional methodological design, with non-probability sampling for convenience, following the ethical principles of research involving human subjects of the declaration of Helsinki (Puri, et al. 2009; Thomas, Nelson, \& Silverman, 2015). In total, thirty-two university student athletes of the Faculty of Sports 
of the Autonomous University of Baja California participated. The average age of the participating subject was of $21.4 \pm 3.6$ years ( 17 men and 15 women).

\section{Instruments and Procedures}

To determine the levels of physical activity, the short form, Spanish version, of the International Physical Activity Questionnaire (IPAQ) was utilized (Craig, et al. 2003). Evaluating university athletes before and during the COVID19 social confinement.

The IPAQ questionnaire takes into account physical activity performed in the last 7 days, including activities from the action of walking to activities considered as vigorous. The methodology of the IPAQ questionnaire quantifies the days and minutes of performed physical activity to determine a classification, depending on the METs value, in three levels: high, moderate, and low, thus all types of walking include an average MET value of 3.3. Excluding walking, all moderate intensity physical activities were classified as 4 , and vigorous intensity activities as 8 .

With these assigned values, the MET-minutes/week were calculated using the following formulas:

-walking=3.3 $\mathrm{MET}^{*}$ minutes of walking * days practiced perweek.

-moderate physical activity $=4 \mathrm{MET} *$ minutes of moderate physical activity $*$ days practiced per week.

-vigorous physical activity $=8 \mathrm{MET} *$ minutes of vigorous physical activity * days practiced per week.

Sum $=$ walk + moderate physical activity + vigorous physical activity.

Once the sum was obtained, the subjects were classified into three levels of physical activity using the following criteria:

1. High level of physical activity, with two criteria:

Vigorous physical activity at least three days a week achieving a total of at least 1500 MET-minutes/week.

Seven or more days of any combination of walking with moderate, and/or vigorous physical activity, achieving a total of at least 3,000 MET-minutes / week.

2. Moderate level of physical activity was classified using any of the following three criteria:

Three or more days of vigorous physical activity for at least 20 minutes per day.

Five or more days of moderate physical activity or walking for at least 30 minutes per day.

Five or more days of any of the combinations of walking, moderate, or vigorous physical activity achieving as minimum a total of physical activity of at least 3,000 MET-minutes/ week.

3. Low level of physical activity People who had walked, or performed another moderate or vigorous physical activity with a cumulative daily duration of at least $10 \mathrm{~min}$, but who did not meet the criteria for moderate or high levels were classified into this level.

\section{Statistical Analysis}

For the analysis of the data, the SPSS Version 23.0 program was utilized, descriptively classifying the variable into three levels: high, moderate and low, depending on the METs value. Statistical inferential analysis using the Student's t-test for independent samples took into account the research design with fixed variables of two groups 1) before the COVID19 confinement or 2) during the COVID-19 confinement and MET's physical activity as a numerical random variable performed by university athletes. The percentage difference ( $\ddot{\mathrm{A}} \%$ ) was also determined. The normality of the groups and the homogeneity of variance of the data were verified through the Kolmogorov-Smirnov test with a degree of significance of P-Value e» 0.05 .

\section{Results}

Descriptively, Table 1 presents the percentage distribution of the level of physical activity in future graduates in physical activity and sport before and during the COVID19 social distancing.

Inferential statistics using the student's t-test for independent sampling, calculating the variance equality at a level of ád» 0.05 , showed significant differences in weekly energy expenditure of physical activity $(\mathrm{p}=.005)$, expressed in MET/week (metabolic equivalent), with higher values before than during the COVID-19 confinement.

Table 1

Percentage distribution of physical activity levels of university student athletes, before and during confinement due to the COVID-19 pandemic.

\begin{tabular}{ccc}
\multicolumn{2}{c}{ during confinement due to the COVID-19 pandemic. } & \\
\hline Level of Physical Activity & Before & During \\
& COVID-19 & COVID-19 \\
\hline Low & $3.6 \%$ & $10.9 \%$ \\
Moderate & $5.2 \%$ & $6.8 \%$ \\
High & $91.2 \%$ & $82.3 \%$ \\
\hline
\end{tabular}

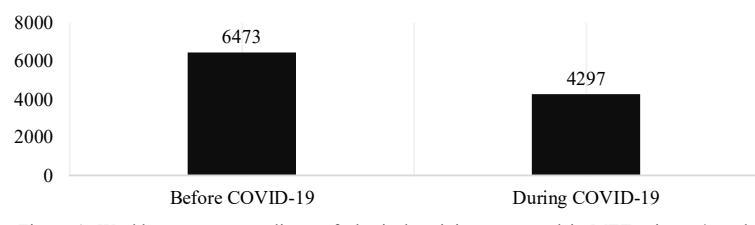

Figure 1. Weekly energy expenditure of physical activity, expressed in MET minutes/ week (metabolic equivalents), in university athletes, before and during the COVID-19 confinement.

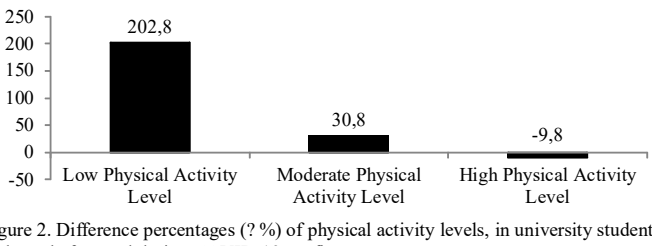
Figure 2. Difference percentages (?\%) of physical activity levels, in university studen athletes, before and during COVID-19 confinement.

\section{Discussion}

The main result of the study was that during COVID-19 confinement, the physical activity MET/week evaluated by the IPAQ questionnaire, decreased significantly by $-33.6 \ddot{\mathrm{A}} \%$, compared to the physical activity performed before the COVID-19 confinement. The prevalence of sports injuries is somewhat common in university athletes (Moo Peña, \& Solís Briceño, 2019). Of the subjects participating in this research, $5.6 \%$ reported being injured at the time of the assessment, which limited as a whole or in part sports practice, the aforementioned favored a low accumulation of MET/ week.

Despite the fact that university athletes decreased MET/ week from 6473 to 4297, these COVID-19 confinement values are even higher when compared to non-athlete university students (Moreno-Arrebola, et al. 2018). Hypothetically, we assume that the limitation of access to sports spaces and training sessions favored less practice of physical activity 
since universities closed the facilities to prevent COVID-19 infections (Wang, et al., 2020; Toresdahl, \& Asif, 2020; BaenaMorales, et al., 2020). Regarding physical activity levels, when comparing the results with other research that utilized the same methodological procedure, a higher trend of physical activity classified as high was observed in the subjects of our study (82.3 vs 40.5), compared to non-athlete university students, even doubling the values, during COVID-19 confinement (Hall-López, Ochoa-Martínez, \& Muñiz Murguía, 2013). We believe that despite the loss of physical activity, the athlete followed the recommendations to exercise at home during COVID-19 confinement (Cortis, et al., 2020). We consider that the work done by coaches to follow up at a distance as an alternative to maintain physical condition, for when sports competitions are once reopened this is a factor that kept the level of physical activity high (Álvarez Pérez, et al. 2013; Leng, \& Phua, 2020). A dependency on exercise of the university athlete has also been identified as an indicator (Reche García, Martínez Rodríguez, \& Ortín Montero, 2015) and the lack of sports practice another factor that favors the Burnout Syndrome (Reynaga-Estrada, et al. 2017).

It could be established that due to being university student athletes, physical activity of moderate to vigorous intensity is part of their daily actions, however, the degree of difficulty is that they must also harmonize in their time the learning processes in their future profession (Álvarez Pérez, \& López Aguilar, 2012).

The performed research has limitations, due to it being conducted through a cross-sectional design, without evaluating other co-variables that could influence the study since the practice of physical activity of moderate to vigorous intensity in university students is multifactorial (MorenoArrebola, et al. , 2018), nevertheless, the instrument utilized to assess physical activity is reliable and IPAQ has been reported as the most widely used in that population (MellaNorambuena, et al., 2019) and was utilized in a timely manner in a time of health crisis using the Google Drive tool to assess the trend (Álvarez Ferrón \& Sánchez Cañizares, 2014).

\section{Conclusion}

University athletes perform optimal levels of physical activity according to their sports discipline, and have higher levels of physical activity than non-athlete university students. Despite the significant decrease in physical activity MET/week during COVID-19 confinement, to a greater extent the levels of physical activity were high, harmonizing the learning processes in their future profession and dedicating themselves to performing physical activity at home.

\section{References}

Álvarez Ferrón, M., \& Sánchez Cañizares, L. (2014). Conocimiento, valoración y utilización, por parte del alumnado, de «Google Drive» como herramienta de trabajo cooperativo. EnseñAnza \& Teaching: Revista Interuniversitaria De Didáctica, 32(2), 23-52. doi:10.14201/et20143212352

Álvarez Pérez, P., \& López Aguilar, D. (2012). Armonización entre proceso de aprendizaje y práctica deportiva en universitarios deportistas de alto nivel. (Harmonization Between Learning Process and Sport Practice in High Level University Athletes).. Cultura, Ciencia y Deporte, 7(21), 201-212. doi:http://dx.doi.org/10.12800/ccd.v7i21.85

Álvarez Pérez, Pedro R., \& López Aguilar, David. (2013). Tutoría académica personalizada para estudiantes universitarios deportistas de alto nivel. Revista Brasileira de Orientação Profissional, 14(2), 239-253. Recuperado em 05 de junho de 2020, de http://

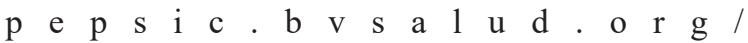
scielo.php?script=sci_arttext\&pid=S167933902013000200009\&lng-pt\&tlng=es.

Álvarez Pérez, P., Pérez-Jorge, D., González Ramallal, M., \& López Aguilar, D. (2015). La formación universitaria de deportistas de alto nivel: análisis de una compleja relación entre estudios y deporte (High level sportsmen's and women's university studies: an analysis on the difficult relationship between studies and sport). Retos, 0(26), 94100. https://recyt.fecyt.es/index.php/retos/article/view/ 34408

Baena-Morales, S., López-Morales, J., \& García-Taibo, O. (2020). La intervención docente en educación física durante el periodo de cuarentena por COVID-19 (Teaching intervention in physical education during quarantine for COVID-19). Retos, (39), 388-395. https://doi.org/10.47197/ retos.v0i39.80089

Blanco García, P., \& Burillo Naranjo, P. (2017). Los deportistas de élite en el sistema universitario español (Elite athletes in the Spanish university system). Retos, 0(33), 162-168. https://recyt.fecyt.es/index.php/retos/article/view/55773

Blocken, B., Malizia, F., van Druenen., T., \& Marchal, T. (2020). Towards aerodynamically equivalent COVID-19 $1.5 \mathrm{~m}$ social distancing for walking and running. Urban Physics, Wind Engineering \& Sports Aerodynamics. Preprint. https://www.euroga.org/system/1/user_files/files/000/ $045 / 111 / 45111 / 150 \mathrm{~d} 3060 \mathrm{c} /$ original/ Social_Distancing_v20_White_Paper.pdf

Craig, C. L., Marshall, A. L., Sjostrom, M., Bauman, A. E., Booth, M. L., Ainsworth, B. E., . . . Oja, P. (2003). International physical activity questionnaire: 12 -country reliability and validity. Medicine \& Science in Sports \& Exercise, 35(8), 1381-1395. doi: 10.1249/ 01.MSS.0000078924.61453.FB

Corbí Santamaría, M., Palmero-Cámara, C., \& Jiménez-Palmero, A. (2018). Diferencias en los motivos hacia la actividad física de los universitarios según nivel de actividad y su relación con la satisfacción del servicio deportivo universitario (Differences in motives toward physical activity regarding physical activity level. Retos, O(35), 191195. https://recyt.fecyt.es/index.php/retos/article/view/ 62284

Corsini, A., Bisciotti, G N., Eirale, C., \& Volpi, P.(2020). Football cannot restart soon during the COVID-19 emergency! A critical perspective from the Italian experience and a call for action. British Journal of Sports Medicine, 0(0), 1-2. doi: 10.1136/bjsports-2020-102306

Cortis, C., Giancotti, G., Rodio, A., Bianco, A., \& Fusco, A. (2020). Home is the new gym: exergame as a potential tool to maintain adequate fitness levels also during quarantine. Human Movement, 21(4), 1-9. https://doi.org/ 
10.5114/hm.2020.94826

de Oliveira Neto, L., de Oliveira Tavares, V. D., Schuch, F. B., \& Lima, K. C. (2020). Coronavirus Pandemic (SARS-COV2): Pre-Exercise Screening Questionnaire (PESQ) for Telepresential Exercise. Frontiers in public health, 8, 146. https://doi.org/10.3389/fpubh.2020.00146

Dixit S. (2020). Can moderate intensity aerobic exercise be an effective and valuable therapy in preventing and controlling the pandemic of COVID-19?. Medical Hypotheses, 143, 109854. https://doi.org/10.1016/ j.mehy.2020.109854

Gallego, V., Nishiura, H., Sah, R., \& Rodriguez-Morales, A. J. (2020). The COVID-19 outbreak and implications for the Tokyo 2020 Summer Olympic Games. Travel medicine and infectious disease, 34, 101604. https://doi.org/ 10.1016/j.tmaid.2020.101604

Hall-López, J.A., Ochoa-Martínez, P. Y., \& Muñiz Murguía, J. J. (2013). Nivel de actividad física en estudiantes de la Universidad de Colima. Revista de Educación, Motricidad e Investigación E-motion, 02, 1-6. http:// rabida.uhu.es/dspace/handle/10272/8064

Hammami, A., Harrabi, B., Mohr, M., \& Krustrup, P. (2020): Physical activity and coronavirus disease 2019 (COVID19): specific recommendations for home-based physical training. Managing Sport and Leisure, 4, 1-6. DOI: 10.1080/23750472.2020.1757494

Leng, H. K., \& Phua, Y. X. (2020) Athletes as role models during the COVID-19 pandemic. Managing Sport and Leisure, 25(4), 1-5. DOI: 10.1080/23750472.2020.1762330

Mella-Norambuena, J., Celis, C., Sáez-Delgado, F., Aeloiza, A., Echeverria, C., Nazar, G., \& Petermann-Rocha, F. (2019). Revisión sistemática de práctica de actividad física en estudiantes universitarios. Revista Iberoamericana de Ciencias de la Actividad Física y el Deporte, 8(2), 37 58. DOI: http://dx.doi.org/10.24310/riccafd.2019.v8i2.6452

Moo Peña, J. C., \& Solís Briceño, O. B. (2019) Resiliencia y lesiones en deportistas universitarios Revista de Psicología de la Salud (New Age) 7, (1), 134-151. http:/ /revistas.innovacionumh.es/index.php?journal=psic ologiasalud\&page=article\&op=view\&path $\% 5 \mathrm{~B} \% 5 \mathrm{D}=1$ $515 \&$ path $\% 5 \mathrm{~B} \% 5 \mathrm{D}=607$

Moreno-Arrebola, R., Fernández-Revelles, A., LinaresManrique, M., \& Espejo-Garcés, T. (2018). Revisión sistemática sobre hábitos de actividad física en estudiantes universitarios. Sportis. Scientific Journal of School Sport, Physical Education and Psychomotricity, 4(1), 162-183.https://doi.org/10.17979/ sportis.2018.4.1.2062
Ochoa-Martinez, P., Hall-López, J., Solano-Pineda, I., Monreal Ortiz, L., Chacón-Araya, Y., \& Moncada-Jiménez, J. (2017). Prediction of body fat through body adiposity index and bioelectrical impedance analysis in a sample of physically active Mexican students (Predicción de grasa corporal mediante el índice de adiposidad corporal y análisis de impedancia bioeléctrica en un. Retos, O(34), 128-131. https://recyt.fecyt.es/index.php/retos/article/view/55185

Puri, K. S., Suresh, K. R., Gogtay, N. J., \& Thatte, U. M. (2009). Declaration of Helsinki, 2008: Implications for stakeholders in research. Journal of Postgraduate Medicine, 55(2), 131-134. Doi 10.4103/0022-3859.52846

Reche García, C., Martínez Rodríguez, A., \& Ortín Montero, F. (2015). Dependencia al ejercicio físico e indicadores del estado de ánimo en deportistas universitarios. Cuadernos De Psicología Del Deporte, 15(2), 21-26. https://revistas.um.es/cpd/article/ view/233781

Reynaga-Estrada, P., Mena Robles, D. A., Valadez Jiménez, A. (2017). Síndrome de burnout en deportistas universitarios mexicanos. Revista de psicología del deporte, 26(2), 209-214. https://ddd.uab.cat/record/ 181315

Rico-Díaz, J., Arce-Fernández, C., Padrón-Cabo,A., PeixotoPino, L., \& Abelairas-Gómez, C. (2019). Motivaciones y hábitos de actividad física en alumnos universitarios (Motivations and physical activity habits in university students). Retos, 36(36), 446-453. https://recyt.fecyt.es/ index.php/retos/article/view/69906

Sacheck, J. M., Kuder, J. F., \& Economos, C. D. (2010). Physical fitness, adiposity, and metabolic risk factors in young college students. Medicine \& Science in Sports \& exercise, 42(6), 10391044. doi: 10.1249/MSS.0b013e3181c9216b

Thomas, J. R., Nelson, J. K., \& Silverman, S. J. Research Methods in Physical Activity (7th. Ed.). Human Kinetics. 2015. Champaign, Ilinois: Human Kinetics. Available: http://www.humankinetics.com/products/all-products/ research-methods-in-physical-activity-7th-edition

Toresdahl, B. G., \& Asif, I. M. (2020). Coronavirus Disease 2019 (COVID-19): Considerations for the Competitive Athlete. Sports Health, 12(3), 221-224. https://doi.org/ 10.1177/1941738120918876

Wang, C., Cheng, Z, Yue, X. G., \& McAleer, M. (2020). Risk Management of COVID-19 by Universities in China. Journal of Risk and Financial Management, 13(2), 1-6. https://doi.org/10.3390/jrfm13020036

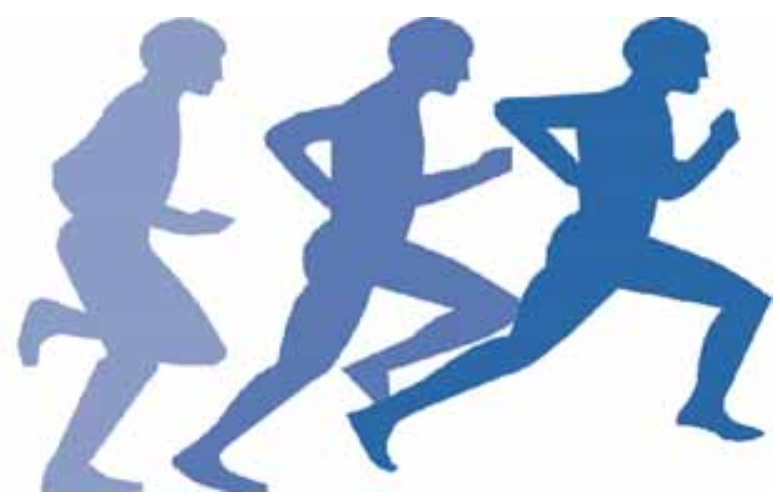

